\title{
COMPARATIVE STUDY OF THE IMPACTS OF CONVENTIONAL FREEZING AND DEHYDROFREEZING ON APPLE FRUIT QUALITY DURING STORAGE
}

\author{
L. Ben Haj Said ${ }^{\mathrm{a}, \mathrm{b} *}$, S. Bellagha ${ }^{\mathrm{a}}$ and K. AllaF ${ }^{\mathrm{b}}$ \\ ${ }^{a}$ Laboratory of Valorization of Tunisian Natural Resources and Food Heritage through Innovation (UR17AGR01), \\ Carthage University, Tunisian National Institute of Agronomy, Tunis. Tunisia \\ ${ }^{\mathrm{b}}$ Laboratory of Engineering Science for Environment (UMR 7356 CNRS), La Rochelle University, 17042 La \\ Rochelle Cedex 1. France
}

(Received: 15 October 2019; accepted: 7 March 2020)

\begin{abstract}
The present study deals with the impact of storage time on the quality of dehydrofrozen versus conventionally frozen apple. Samples were submitted to freezing as fresh fruit or following the first stage of air drying. The quality was evaluated along a freezing storage period of 18 months under $-18{ }^{\circ} \mathrm{C}$. Thaw exudate water (TEW), total colour difference (TCD), and total polyphenol content (TPC) of dehydrofrozen/thawed samples were assessed regarding the water content (W) versus the frozen storage time (FST) (0-18 months). Dehydrofreezing exhibited significant effects on TEW and TCD of dehydrofrozen/thawed apples. Indeed, the lower the W, the lower the TEW content and TCD of partially dried frozen/thawed samples. TPC losses were significant for samples without any pre-dehydration stage and decreased when initial water content decreased. The 18 -month frozen storage at $-18^{\circ} \mathrm{C}$ had the most insignificant effects on all quality response variables for the previously most dried samples. Thus, adequate drying of fruit before freezing is a relevant way to maintain the stability of fruit quality during long-term storage.

Keywords: apple fruit, dehydrofreezing, frozen storage, thaw exudate water, colour, polyphenol
\end{abstract}

Dehydrofreezing has been defined and developed as a preservation method of fruit and vegetables with high water content. This process involves a phase of partial dehydration before freezing in order to reduce the risk of large crystal ice formation. Thus, such a partial dehydration preserves the cell walls from damage and destruction that the freezing and thawing processes normally cause due to the difference between the volumes of water and ice. Previous studies have shown that dehydrofreezing reduces time and increases the rate of freezing (RAMALlo \& MASCHERONI, 2010). This combined process reduces exudate water during the thawing stage of dehydrofrozen fruit and vegetables (MAESTRELLI et al., 2001), and thus improves the textural firmness (BEN HAJ SAID et al., 2016).

However, it is well known that natural products also undergo quality changes and losses throughout subsequent storage in the frozen state. Physical changes, such as recrystallisation of ice, can occur during storage at negative temperatures. This storage therefore leads to a deterioration of textural and nutritional quality and can therefore reverse the benefits of rapid freezing.

To the best of our knowledge, only information about the impact of long-period frozen storage in the preservation ratio of nutritional quality and the bioactive composition is available for conventional freezing. Thus, this present study focused on performing a comparative analysis of the impact of such frozen storage in the case of dehydrofreezing

\footnotetext{
* To whom correspondence should be addressed.

Phone: +216 71287 110; fax: +216 71799 391; e-mail: benhajsaidleila@yahoo.fr
} 
versus conventional freezing of apple fruit. The impacts of frozen storage at $-18{ }^{\circ} \mathrm{C}$ for 18 months on the amount of water exuded during thawing, the colour, and the total polyphenol content of the thawed fruit were studied.

\section{Materials and methods}

\subsection{Process treatments}

1.1.1. Partial drying. Drying of Golden delicious apple discs of $10.0 \pm 0.2 \mathrm{~mm}$ thickness $(25 \pm 2 \mathrm{~g})$ was carried out in an air dryer (Memmert: Universal Oven UNB Model 800$)$ under constant conditions of $45^{\circ} \mathrm{C}$ as air temperature, $2 \mathrm{~m} \mathrm{~s}^{-1}$ as air velocity, and $12 \%$ as air relative humidity. Drying was stopped when the desired water contents of 200,100 , and $30 \% \mathrm{db}$ (dry basis) were reached. Drying experiments were done in triplicate.

1.1.2. Freezing. Fresh and partially air dried apple samples with different water contents were frozen in a freezer (Whirlpool Model AFG $363 / \mathrm{G}$, Italy) at $-18^{\circ} \mathrm{C}$. Freezing experiments were done in triplicate.

1.1.3. Frozen storage. Frozen and dehydrofrozen apple samples were stored at $-18{ }^{\circ} \mathrm{C}$ for 18 months. Samples were retrieved each month during the first 3 months of storage, afterwards each 3 months until the end of the storage period for quality assessments.

1.1.4. Thawing. Frozen and dehydrofrozen apple samples were thawed in a refrigerator (FAR Model RT 140, Romania) at $4{ }^{\circ} \mathrm{C}$ overnight just before starting the different analyses. Thawing experiments were done in triplicate.

\subsection{Quality assessments}

1.2.1. Thaw exudate water (TEW) determination. TEW was determined, in triplicates, according to the method described by BEN HAJ SAID and co-workers (2016).

1.2.2. Colour measurements. A colorimeter (Konica Minolta CR-410, Japan) was used to measure L, a, and b parameters in triplicates. Total colour difference (TCD) was calculated using the equation (Eq. 1) as follows:

$$
T C D=\sqrt{\left(\mathrm{L}-\mathrm{L}_{0}\right)^{2}+\left(\mathrm{a}-\mathrm{a}_{0}\right)^{2}+\left(\mathrm{b}-\mathrm{b}_{0}\right)^{2}}
$$

where $\mathrm{L}_{0}, \mathrm{a}_{0}, \mathrm{~b}_{0}$ are the colour parameters of the fresh or dried samples, while $\mathrm{L}, \mathrm{a}, \mathrm{b}$ are the colour parameters of the frozen or dehydrofrozen thawed samples.

1.2.3. Total polyphenol content (TPC). TPC was assayed for differently treated samples in triplicates (ZHAO et al., 2016).

1.2.4. Statistical analysis. The data were reported as mean values \pm standard deviation (SD). Bifactorial analysis of variance (ANOVA) and multiple range test (SNK) were carried out at a confidence level of $95 \%(\mathrm{P}<0.05)$ using the Statistical Package for the Social Sciences (SPSS) version 20. 


\section{Results and discussion}

\subsection{Thaw exudate water (TEW)}

Table 1 shows the TEW of apple samples frozen, dehydrofrozen, and during long-term frozen storage at $-18^{\circ} \mathrm{C}$ for 18 months.

Table 1. Effect of conventional freezing and dehydrofreezing of apples on thaw exudate water during storage

\begin{tabular}{|c|c|c|c|c|}
\hline \multirow{3}{*}{$\begin{array}{l}\text { Frozen storage } \\
\text { time } \\
\text { (months) }\end{array}$} & \multicolumn{4}{|c|}{ Thaw exudate water $(\%)$} \\
\hline & \multicolumn{4}{|c|}{ Water content $(\% \mathrm{db})$} \\
\hline & 700 & 200 & 100 & 30 \\
\hline 0 & $14.64 \pm 0.92^{\mathrm{bA}}$ & $3.42 \pm 0.57^{\mathrm{aB}}$ & $0.38 \pm 0.13^{\mathrm{aC}}$ & $0.23 \pm 0.13^{\mathrm{aC}}$ \\
\hline 1 & $15.03 \pm 1.22^{\mathrm{bA}}$ & $3.47 \pm 2.21^{\mathrm{aB}}$ & $0.75 \pm 0.32^{\mathrm{aC}}$ & $0.25 \pm 0.19^{\mathrm{aC}}$ \\
\hline 2 & $16.70 \pm 2.05^{\mathrm{abA}}$ & $3.89 \pm 1.38^{\mathrm{aB}}$ & $0.63 \pm 0.10^{\mathrm{aC}}$ & $0.33 \pm 0.08^{\mathrm{aD}}$ \\
\hline 3 & $17.60 \pm 1.77^{\mathrm{abA}}$ & $2.88 \pm 1.81^{\mathrm{aB}}$ & $0.88 \pm 0.18^{\mathrm{aC}}$ & $0.23 \pm 0.05^{\mathrm{aD}}$ \\
\hline 6 & $17.18 \pm 1.48^{\mathrm{abA}}$ & $3.68 \pm 1.87^{\mathrm{aB}}$ & $0.75 \pm 0.18^{\mathrm{aC}}$ & $0.27 \pm 0.24^{\mathrm{aC}}$ \\
\hline 9 & $17.13 \pm 1.49^{\mathrm{abA}}$ & $3.81 \pm 1.26^{\mathrm{aB}}$ & $0.31 \pm 0.31^{\mathrm{aC}}$ & $0.21 \pm 0.16^{\mathrm{aC}}$ \\
\hline 12 & $20.18 \pm 0.63^{\mathrm{aA}}$ & $3.46 \pm 1.58^{\mathrm{aB}}$ & $0.64 \pm 0.20^{\mathrm{aC}}$ & $0.32 \pm 0.34^{\mathrm{aC}}$ \\
\hline 15 & $19.08 \pm 1.32^{\mathrm{abA}}$ & $3.53 \pm 1.78^{\mathrm{aB}}$ & $0.33 \pm 0.32^{\mathrm{aC}}$ & $0.22 \pm 0.13^{\mathrm{aC}}$ \\
\hline 18 & $19.77 \pm 1.05^{\mathrm{abA}}$ & $4.96 \pm 1.11^{\mathrm{aB}}$ & $0.83 \pm 0.26^{\mathrm{aC}}$ & $0.38 \pm 0.06^{\mathrm{aD}}$ \\
\hline
\end{tabular}

Different letters $(A-D)$ within the same row differ significantly $(\mathrm{P}<0.05)$. Different letters $(\mathrm{a}-\mathrm{b})$ within the same column differ significantly $(\mathrm{P}<0.05)$

After thawing at a surrounding medium temperature of $4{ }^{\circ} \mathrm{C}$, TEW recovered from frozen fresh samples was approximately of $15 \mathrm{~g} / 100 \mathrm{~g}$ initial water. These samples $(700 \% \mathrm{db}$ initial water content) gave back significantly more TEW than all partially dried samples after freezing/thawing processes. This amount of TEW was significant, and increased slightly during the 18 months of frozen storage at $-18{ }^{\circ} \mathrm{C}$ with a significant effect of FST on TEW. According to GonCALVEs and co-workers (2011), during frozen storage, ice crystal recrystallisation may cause loss of cell turgor causing a leakage of fruit cell content and a decrease of cell water holding capacity, resulting in TEW increase during storage.

Similar results, concerning TEW increase during frozen storage, were obtained for different frozen/thawed fruits and vegetables such as broccolis (GoNCALVES et al., 2011).

Before storage, TEW recovered from samples with $200 \% \mathrm{db}$ water content was lower than $4 \mathrm{~g} / 100 \mathrm{~g}$ initial water and lower than $0.5 \mathrm{~g} / 100 \mathrm{~g}$ initial water for 100 and $30 \% \mathrm{db}$ water content samples. This low TEW level reveals high textural and structural quality issued from better preservation of cell walls. This contributes to an inhibition of water loss from the internal cells (BEN HAJ SAID et al., 2016). The smaller the amount of residual water in the sample tissue, the lower the TEW. Similar results were obtained for other fruits such as strawberry (SORMANI et al., 1999), apple (BEN HAJ SAID et al., 2016), and quince (HAJJI et al., 2019) partially dehydrated by air drying prior to freezing.

In the case of strawberry fruit, the significantly lower decrease in TEW is explained by a much better tissue organisation and relatively few cell ruptures observed in the partially 
dried samples prior to the freezing process (SORMANI et al., 1999). Indeed, a low severity air drying causes no significant structural damage in various fruits and vegetables such as strawberry. Whereas, freezing of high water content samples (without any dehydration pretreatment) systematically results in plasmolysed cells and loss of continuity and thinning of the cell walls (Sormani et al., 1999). According to RAMALlo and MASCHERONI (2010), the decrease of TEW for frozen pineapple samples previously air dried is due to greater dehydration degree of cells located on the surface, inhibiting water migration. Mechanical measurements carried out on pineapple fruit showed that air dried samples presented higher resistance than fresh fruit during freezing and thawing processes (RAMALLO \& MASCHERONI, 2010).

The most important point worth to be highlighted here is that, for previously dehydrated apple samples, TEW remained constant and weak or even negligible during the whole storage period. Partial removal of water before fruit freezing appears to be a possible way to preserve the structural and textural properties of frozen/thawed fruit and improve its stability during storage.

\subsection{Colour}

The colour parameter values of $\mathrm{L}, \mathrm{a}$, and $\mathrm{b}$ measured for fresh and partially dried apple samples before and after freezing/thawing processes are shown in Figure 1.

In the case of fresh sample, the colour parameters showed a negative a value, which represents green colour, positive $b$ value indicating yellow colour, and high $L$ value $(\sim 100)$ for high lightness. As it is shown in Figure 1, air drying at $45^{\circ} \mathrm{C}$ caused significant changes in all colour parameters of partially dried apple with different water contents, as compared with the fresh samples. Colour losses could be ascribed to browning reactions, which occurred during drying and caused pigmented compound formation. Thus, luminance of samples decreased after air drying (Fig. 1A). The impact of freezing/thawing on apple luminance is important for high water content levels. This effect decreased with water content decrease and remained insignificant for low water content samples $(30 \% \mathrm{db})$. Thus, air drying resulted in a final product that darkened upon thawing. Moreover, air drying caused a significant decrease of b value indicting low yellow colour of apple samples (Fig. 1C). Negative a value, which represents green colour, increased significantly after air drying (Fig. 1B). A shift occurred in the parameter a from a negative value (greenish) for the fresh apples to a positive value (reddish) for the dried samples with a water content of $200 \% \mathrm{db}$.

The impact of freezing/thawing on a parameter equally decreased with decreasing water content and remained insignificant for low water content samples $(30 \% \mathrm{db})$. This is due to low water activity at this humidity level. Furthermore, the global effect of freezing and thawing processes on colour decreased and became negligible for samples with low water content. Indeed, the total colour difference (TCD) varied from 33.56 to 15.59 for samples with initial water contents of 700 and $30 \% \mathrm{db}$, respectively (Table 2). The freezing/thawing effect decrease is explained by the lower water activity of samples and consequently lower rate of enzymatic browning reactions (ZHAO et al., 2016). The freezing impact decrease on fruit colour is also attributed to the drying step, which caused the reduction of phenolase activity and enzymatic browning (ForNI et al., 1997).

On the other hand, partial removal of water from fruit cells protected product colour due to lower structural damage as a result of freezing decreasing the enzymatic browning in damaged tissue (ZHAO et al., 2016). 

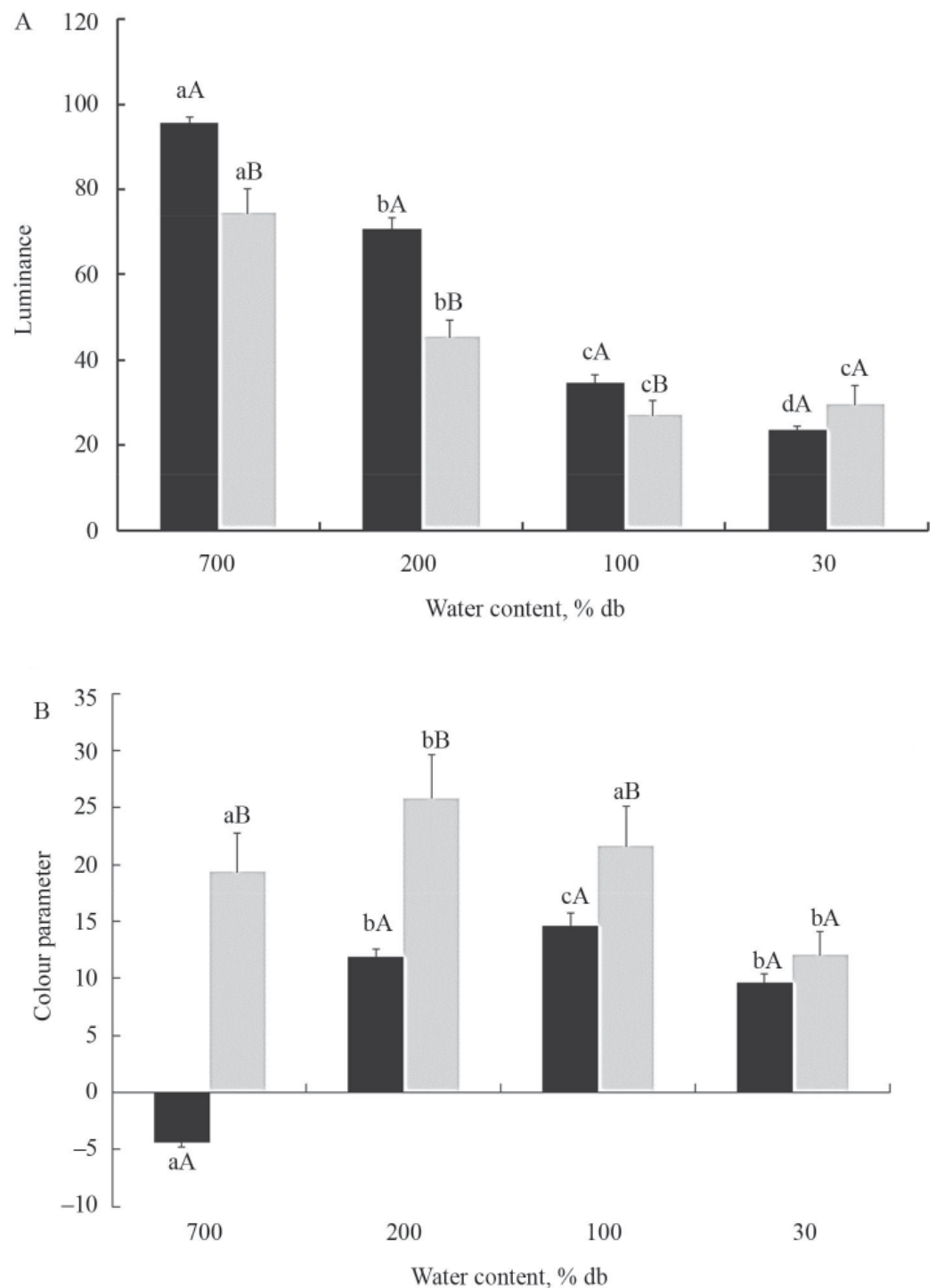

Fig. 1. Effect of freezing and thawing on colour parameters of fresh and partially dried apple (A): L, (B): a, and $(\mathrm{C})$ : b

Values for the same treatment having the same letter (a, b, c, and d) are not significantly different. Values for the same water content level having the same letter (A and B) are not significantly different

口: Drying; : : Dehydrofreezing/thawing 


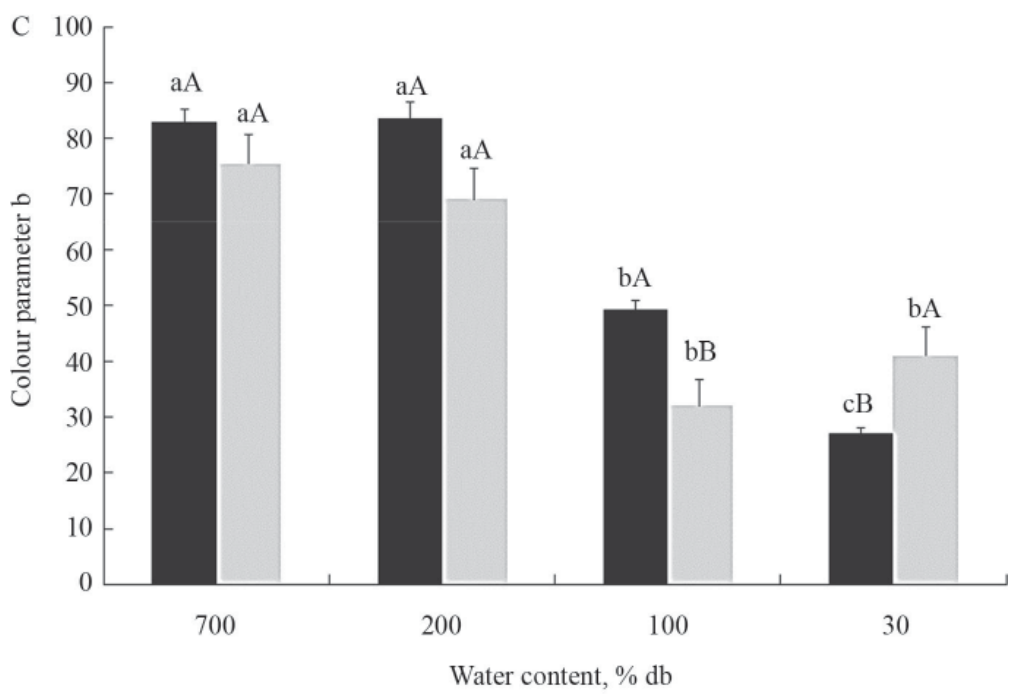

Fig. 1. cont.

\begin{tabular}{|c|c|c|c|c|}
\hline \multirow{3}{*}{$\begin{array}{l}\text { Frozen storage } \\
\text { time } \\
\text { (months) }\end{array}$} & \multicolumn{4}{|c|}{ Total colour difference (-) } \\
\hline & \multicolumn{4}{|c|}{ Water content $(\% \mathrm{db})$} \\
\hline & 700 & 200 & 100 & 30 \\
\hline 0 & $33.56 \pm 5.94^{\mathrm{aA}}$ & $31.66 \pm 2.06^{\mathrm{aA}}$ & $21.88 \pm 7.71^{\mathrm{aA}}$ & $15.59 \pm 6.15^{\mathrm{aB}}$ \\
\hline 1 & $29.28 \pm 3.49^{\mathrm{aA}}$ & $30.47 \pm 6.91^{\mathrm{aA}}$ & $25.14 \pm 5.76^{\mathrm{aA}}$ & $15.61 \pm 4.53^{\mathrm{aB}}$ \\
\hline 2 & $28.20 \pm 5.19^{\mathrm{aA}}$ & $30.15 \pm 6.84^{\mathrm{aA}}$ & $25.72 \pm 2.86^{\mathrm{aA}}$ & $14.03 \pm 6.82^{\mathrm{aB}}$ \\
\hline 3 & $31.44 \pm 7.12^{\mathrm{aA}}$ & $34.62 \pm 5.98^{\mathrm{aA}}$ & $22.57 \pm 3.67^{\mathrm{aA}}$ & $10.91 \pm 3.96^{\mathrm{aB}}$ \\
\hline 6 & $32.70 \pm 1.93^{\mathrm{aA}}$ & $32.74 \pm 8.09^{\mathrm{aA}}$ & $26.51 \pm 7.45^{\mathrm{aA}}$ & $12.14 \pm 5.66^{\mathrm{aB}}$ \\
\hline 9 & $32.71 \pm 2.42^{\mathrm{aA}}$ & $32.48 \pm 5.63^{\mathrm{aA}}$ & $21.09 \pm 2.86^{\mathrm{aA}}$ & $15.10 \pm 7.52^{\mathrm{aB}}$ \\
\hline 12 & $27.74 \pm 6.21^{\mathrm{aA}}$ & $32.80 \pm 4.23^{\mathrm{aA}}$ & $25.20 \pm 7.54^{\mathrm{aA}}$ & $13.95 \pm 6.91^{\mathrm{aB}}$ \\
\hline 15 & $30.94 \pm 5.88^{\mathrm{aA}}$ & $30.66 \pm 5.19^{\mathrm{aA}}$ & $20.90 \pm 6.39^{\mathrm{aA}}$ & $11.50 \pm 5.79^{\mathrm{aB}}$ \\
\hline 18 & $29.34 \pm 5.47^{\mathrm{aA}}$ & $33.34 \pm 4.71^{\mathrm{aA}}$ & $20.81 \pm 5.19^{\mathrm{aA}}$ & $10.56 \pm 5.69^{\mathrm{aB}}$ \\
\hline
\end{tabular}

Different letters $(\mathrm{A}-\mathrm{D})$ within the same row differ significantly $(\mathrm{P}<0.05)$. Different letters $(\mathrm{a}-\mathrm{b})$ within the same column differ significantly $(\mathrm{P}<0.05)$

Similar results, concerning the protective impact of dehydrofreezing on thawed product colour, were obtained for several fruits and vegetables such as rambutan (LowITHUN \& Charoenrein, 2009) and quince (HaJJI et al., 2019). 
Table 2 shows the total colour difference (TCD) of frozen/dehydrofrozen apple samples after storage at $-18{ }^{\circ} \mathrm{C}$ up to 18 months. It highlights that the TCD was almost constant during this whole storage period. Similar results were obtained for frozen/thawed green beans and carrots (REDMOND et al., 2004) and for dehydrofrozen/thawed melon. Indeed, colour of frozen/thawed melon previously air dehydrated was not influenced by frozen storage for 4 months at $-20^{\circ} \mathrm{C}$ (MAESTRELLI et al., 2001). Sensory evaluation equally showed that the increase of frozen storage time to 120 days did not affect the colour of rambutan fruit (Lowithun \& Charoenrein, 2009).

According to ForNI et al. (1997), the drying step reduced the phenolase activity and thus increased colour stability of dehydrofrozen/thawed apricot during storage.

To conclude, the coupling of air drying and freezing processes induced lesser colour changes at lower water content levels $(100 \%$ and $30 \% \mathrm{db})$ and is very useful for the colour stability of frozen/thawed fruit after adequate frozen storage.

\subsection{Total polyphenol content (TPC)}

Results of TPC in frozen and dehydrofrozen apples with different water contents during frozen storage at $-18{ }^{\circ} \mathrm{C}$ and after thawing are given in Table 3 .

\begin{tabular}{|c|c|c|c|c|}
\hline \multirow{3}{*}{$\begin{array}{l}\text { Frozen storage } \\
\text { time } \\
\text { (months) }\end{array}$} & \multicolumn{4}{|c|}{ Total polyphenol content ( $\mathrm{g} \mathrm{GAE} / 100 \mathrm{~g} \mathrm{db})$} \\
\hline & \multicolumn{4}{|c|}{ Water content $(\% \mathrm{db})$} \\
\hline & 700 & 200 & 100 & 30 \\
\hline 0 & $0.43 \pm 0.04^{\mathrm{aA}}$ & $0.19 \pm 0.03^{\mathrm{aC}}$ & $0.18 \pm 0.01^{\mathrm{aC}}$ & $0.29 \pm 0.01^{\mathrm{aB}}$ \\
\hline 1 & $0.44 \pm 0.01^{\mathrm{aA}}$ & $0.21 \pm 0.03^{\mathrm{aC}}$ & $0.19 \pm 0.01^{\mathrm{aC}}$ & $0.28 \pm 0.01^{\mathrm{aB}}$ \\
\hline 2 & $0.43 \pm 0.05^{\mathrm{aA}}$ & $0.19 \pm 0.01^{\mathrm{aC}}$ & $0.18 \pm 0.01^{\mathrm{aC}}$ & $0.27 \pm 0.01^{\mathrm{aB}}$ \\
\hline 3 & $0.40 \pm 0.03^{\mathrm{aA}}$ & $0.20 \pm 0.02^{\mathrm{aC}}$ & $0.18 \pm 0.01^{\mathrm{aC}}$ & $0.28 \pm 0.01^{\mathrm{aB}}$ \\
\hline 6 & $0.37 \pm 0.03^{\mathrm{aA}}$ & $0.21 \pm 0.02^{\mathrm{aC}}$ & $0.18 \pm 0.01^{\mathrm{aC}}$ & $0.28 \pm 0.01^{\mathrm{aB}}$ \\
\hline 9 & $0.38 \pm 0.02^{\mathrm{aA}}$ & $0.20 \pm 0.01^{\mathrm{aC}}$ & $0.19 \pm 0.01^{\mathrm{aC}}$ & $0.27 \pm 0.01^{\mathrm{aB}}$ \\
\hline 12 & $0.42 \pm 0.02^{\mathrm{aA}}$ & $0.21 \pm 0.01^{\mathrm{aC}}$ & $0.18 \pm 0.01^{\mathrm{aD}}$ & $0.28 \pm 0.01^{\mathrm{aB}}$ \\
\hline 15 & $0.40 \pm 0.05^{\mathrm{aA}}$ & $0.20 \pm 0.01^{\mathrm{aC}}$ & $0.19 \pm 0.02^{\mathrm{aC}}$ & $0.28 \pm 0.01^{\mathrm{aB}}$ \\
\hline 18 & $0.39 \pm 0.02^{\mathrm{aA}}$ & $0.20 \pm 0.01^{\mathrm{aC}}$ & $0.17 \pm 0.01^{\mathrm{aD}}$ & $0.26 \pm 0.01^{\mathrm{aB}}$ \\
\hline
\end{tabular}

Different letters $(\mathrm{A}-\mathrm{D})$ within the same row differ significantly $(\mathrm{P}<0.05)$. Different letters $(\mathrm{a}-\mathrm{b})$ within the same column differ significantly $(\mathrm{P}<0.05)$

Fresh samples present a TPC of $0.62 \mathrm{~g}$ gallic acid equivalent (GAE)/ $100 \mathrm{~g}$ db. Partial air drying resulted in significant reduction of TPC down to $0.26,0.22$, and $0.29 \mathrm{~g} \mathrm{GAE} / 100 \mathrm{~g} \mathrm{db}$ for water contents of 200,100 , and $30 \% \mathrm{db}$, respectively. TPC losses as compared with fresh samples varied from 52 to $64 \%$. According to Korus and LisiewsKa (2011), air drying causes a degradation of phenolic compounds and promotes polyphenol oxidation by the oxygen absorbed from the drying air. Loss in TPC is also ascribed to their use as reactants in the Maillard reaction. 
Similarly, freezing caused significant reduction in TPC. TPC losses were important for apple samples without any pre-dehydration stage and decreased for partially dried apples before freezing. Indeed, for fresh samples, whose initial water content is $700 \% \mathrm{db}$, TPC losses caused by freezing and thawing processes were about $30 \%$. In fact, freezing results in cell decompartmentalisation, allowing reactions between genuine enzymes and their corresponding substrates (HoLzWARTH et al., 2012). Therefore, thawing may already damage phenolic compounds due to their interaction with oxidative activities of enzymes such as polyphenoloxidases (PPO) (CHISARI et al., 2007), which are as active as water activity is high. Similar results were obtained for raspberry fruit freezing (TURKBEN et al., 2010). In truth, the TPC losses are related to linkage of polyphenoloxidase enzymes (PPO) to the cellular wall. The PPO enzymes released after cellular disruption during thawing and the presence of molecular oxygen oxidise the polyphenolics to quinones (TURKBEN et al., 2010). Thus, for partially dried samples with water content of 200,100 , and $30 \% \mathrm{db}$, the TPC losses were only 25,17 , and $5 \%$, respectively.

In addition, the high TPC losses, which were as important as water content of samples, correlated with high TEW. The important structural and textural damage of high water content samples after freezing/thawing processes (BEN HAJ SAID et al., 2016) resulted in high exudate volume and important water-soluble nutrient loss (HolzWARTH et al., 2012). BLANDA and co-workers (2009) studied the impact of osmotic dehydrofreezing of strawberry fruit on TPC changes. These authors reported that such an osmotic dehydration at $30^{\circ} \mathrm{C}$ caused a slight depletion of polyphenols, whereas osmotic dehydrated samples at lower temperature $\left(5^{\circ} \mathrm{C}\right)$ showed higher polyphenol retention. Moreover, a lower final TPC content in pretreated strawberries was found with respect to frozen untreated samples. According to BLANDA and co-workers (2009), these losses are due to the lixiviation of polyphenols in the concentrated sucrose solutions. Similar results were found for mango fruit subjected to osmotic dehydration $\left(30{ }^{\circ} \mathrm{C}, 2 \mathrm{~h}\right)$ with concentration of $45 \%$. Indeed, all osmodehydrofrozen/thawed mangoes showed significantly higher TPC than the un-pretreated frozen/thawed samples (ZHAO et al., 2016).

As it is shown in Table 3, FST had insignificant effect on TPC for frozen and dehydrofrozen/thawed samples with different water contents. No data was found about the impact of coupling air drying and freezing on TPC of fruits and vegetables during their frozen storage. According to KorUs and LISIEwSKA (2011), the quality stability of frozen products and the degree of nutrient decomposition during frozen storage depend not only on the conditions or the period of storage but also on how the frozen products are handled, pretreated, and processed before freezing. This indicates that optimisation of pretreatment and the product properties are the key steps to preserve the nutritional quality of frozen products. In fact, thermal treatments inactivate the enzymes present in vegetable tissue, prevent the oxidation of nutritional and bioactive compounds, and ensure consequently good stability of frozen product quality during storage.

\section{Conclusions}

Frozen storage at $-18{ }^{\circ} \mathrm{C}$ for 18 months had high degradation impact on conventionally frozen apple samples without previous dehydration. 
By removing a part of the water content from apple fruit using air drying, the behaviour of dehydrofrozen samples through the frozen storage period of 18 months at $-18{ }^{\circ} \mathrm{C}$ was much better in terms of preserving various quality parameters.

Air drying as a pretreatment for partial removal of water from apple fruit cells prior to freezing resulted in higher preservation of quality in terms of reduced TEW reflecting better texture quality, colour retention, and better preservation of the bioactive composition. This combined process guarantees the stabilisation of frozen product quality during subsequent long term frozen storage.

\section{References}

Ben Haj Said, L., Bellagha, S. \& Allaf, K. (2016): Dehydrofreezing of apple fruits: freezing profiles, freezing characteristics, and texture variation. Food Bioprocess Tech., 9, 252-261.

Blanda, G., Cerretani, L., Cardinali, A., Barbieri, S., Bendini, A. \& Lercker, G. (2009): Osmotic dehydrofreezing of strawberries: Polyphenolic content, volatile profile and consumer acceptance. $L W T-$ Food Sci. Technol., 42, 30-36.

Chisari, M., Barbagallo, R.N. \& Spagna, G. (2007): Characterization of polyphenol oxidase and peroxidase and influence on browning of cold stored strawberry fruit. J. Agr. Food Chem., 55, 3469-3476.

Forni, E., Sormani, A., Scalise, S. \& Torreggiani, D. (1997): The influence of sugar composition on the colour stability of osmodehydrofrozen intermediate moisture apricots. Food Res. Int., 30, 87-94.

Goncalves, E.M., Abreu, M., Brandao, T.R.S. \& Silva, C.M.L. (2011): Degradation kinetics of colour, vitamin C and drip loss in frozen broccoli (Brassica oleracea L. ssp. Italica) during storage at isothermal and nonisothermal conditions. Int. J. Refrig., 34(8), 2136-2144.

Hajui, W., Gliguem, H., Bellagha, S. \& Allaf, K. (2019): Impact of initial moisture content levels, freezing rate and instant controlled pressure drop treatment (DIC) on dehydrofreezing process and quality attributes of quince fruits. Dry. Technol., 37, 1028-1043.

Holzwarth, M., Korhummel, S., Carle, R. \& Kammerer, D.R. (2012): Evaluation of the effects of different freezing and thawing methods on colour, polyphenol and ascorbic acid retention in strawberries (Fragaria $\times$ ananassa Duch.). Food Res. Int., 48, 241-248.

Korus, A. \& LisiewSKA, Z. (2011): Effect of preliminary processing and method of preservation on the content of selected antioxidative compounds in kale (Brassica oleracea L. var. acephala) leaves. Food Chem., 129, $149-154$.

Lowithun, N. \& Charoenrein, S. (2009): Influence of osmodehydrofreezing with different sugars on the quality of frozen rambutan. Int. J. Food Sci. Tech., 44, 2183-2188.

Maestrelli, A., Lo Scalzo, R., Lupi, D., Bertolo, G. \& Torreggiani, D. (2001): Partial removal of water before freezing: cultivar and pre-treatments as quality factors of frozen muskmelon (Cucumis melo, cv reticulatus Naud.). J. Food Eng., 49, 255-260.

Ramallo, L.A. \& Mascheroni, R.H. (2010): Dehydrofreezing of pineapple. J. Food Eng., 99, 269-275.

Redmond, G.A., Gormley, T.R. \& Butler, F. (2004): The effect of short- and long-term freeze-chilling on the quality of cooked green beans and carrots. Innov. Food Sci. Emerg., 5, 65-72.

Sormani, A., Maffi, D., Bertolo, G. \& Torreggiani, D. (1999): Textural and structural changes of dehydrofreezethawed strawberry slices: Effects of different dehydration pretreatments. Food Sci. Technol. Int., 5, 479-485.

Turkben, C., Sariburun, E., Demir, C. \& Uylaşer, V. (2010): Effect of freezing and frozen storage on phenolic compounds of raspberry and blackberry cultivars. Food Anal. Methods, 3, 144-153.

Zhao, J.H., Liu, F., PANG, X.L., Xiao, H.W., Wen, X. \& Ni, Y.Y. (2016): Effects of different osmo-dehydrofreezing treatments on the volatile compounds, phenolic compounds and physicochemical properties in mango (Mangifera indica L.). Int. J. Food Sci. Tech., 51, 1441-1448. 